\title{
ESTIMATION OF NITRATE DISPERSION-DIFFUSION COEFFICIENTS IN AGRICULTURAL SOIL PROFILE
}

\author{
Viera Kováčová*
}

\begin{abstract}
Nitrate nitrogen $(\mathrm{N})$ is a water-soluble and mobile form of $\mathrm{N}$ that is highly susceptible to leaching. Nitrogen leaching requires water movement and $\mathrm{N}$ present in the soil solution. The quantitative expression for $\mathrm{N}$ leaching includes two factors, the volume of leachate and the $\mathrm{N}$ concentration. Controlling nitrogen leaching presents a major challenge for nitrogen managing. Nitrogen managing strategies regarding rate and time of $\mathrm{N}$ applications must be developed for the specific soils, hydrology, and crop-tillage systems of individual fields.

The diffusion-dispersion coefficient accounts for the various transport-controlled processes which include dispersion (mixing) and diffusion transport of the ions in concert with the liquid movement in the pores of the soil. Experiments studying transport of nitrate ions were conducted by soil column leaching tests in four soil columns separately. The dispersion-diffusion coefficients $\mathrm{D}_{\mathrm{i}}$ were estimated.
\end{abstract}

KEY WORDS: water quality, nitrate ions, transport parameters, dispersion-diffusion coefficients

\section{Introduction}

Nitrogen is a crucial input in agricultural production, but it puts environmental pressure on soil and water contamination. To identify the likely factors influencing nitrogen contamination is one of the most important assignments. It was found out, that increased agricultural activity leads on average to higher nitrate contamination. Nitrogen naturally occurs in an oxidated, reduced and elementary form (gas $\mathrm{N}_{2}$ ). Common forms of inorganic nitrogen comprise nitrates $\mathrm{NO}_{3}^{-}$, nitrites $\mathrm{NO}_{2}^{-}$, ammonium $\mathrm{NH}_{4}{ }^{+}$and cyanides $\mathrm{CN}^{-}$. Nitrogen in the form of amino acids is an essential component of organic matter. Groundwater is polluted by nitrogen compounds from household waste waters, animal wastes, but chiefly fertilizers. Nitrates mostly occur in natural waters as simple $\mathrm{NO}_{3}{ }^{-}$ions, rarely forming complexes. Nitrate content in natural waters varies depending on the vegetation season. Additionally, environmental factors such as precipitation and temperature play an important role. Nitrate leaching from agricultural land is usually considered a non-point source pollution problem, making the specific polluter hard to identify. Consequently, indicators that establish the functional relationship between pollution and agricultural activity in the context of site characteristics are necessary to allow effective policy regulation. Many studies in the literature have developed management options for protecting groundwater quality from nitrate contamination, (Curtin et al., 1994; Džatko, 2004; Kováčová and Velísková, 2013; Wick et al., 2012; Yong et al., 1992).

Input of inorganic $\mathrm{N}$ as a fertilizer is considered essential in modern agriculture in order to satisfy a growing world population. Nitrate $\left(\mathrm{NO}_{3}{ }^{-}\right)$is the one of the principal $\mathrm{N}$ forms taken up by plants. As such, inorganic $\mathrm{N}$ is widely used in agriculture and numerous studies have suggested that leaching of $\mathrm{NO}_{3}{ }^{-}$following high input rates of chemical fertilizer and due to mineralization of organic $\mathrm{N}$ already present in the soils can cause degradation of surface and groundwater quality. The ability of soil to adsorb anions can reduce $\mathrm{NO}_{3}{ }^{-}$ leaching to the deeper horizons and maximilize the $\mathrm{NO}_{3}{ }^{-}$ available for plant nutrition and can thus play a fundamental role in enhancing soil nutrition in some regions, where $\mathrm{NO}_{3}{ }^{-}$availability is often a limiting factor. Previous studies have reported the sorption of $\mathrm{NO}_{3}{ }^{-}$by soils. However, $\mathrm{NO}_{3}^{-}$mobility in soils is mainly controlled by a number of soil properties including iron and aluminium oxide concentrations, organic matter content, $\mathrm{pH}$ of soil solutions and soil texture and clay mineralogy. Authors reported that $\mathrm{NO}_{3}{ }^{-}$sorption was directly related to $\mathrm{NO}_{3}{ }^{-}$concentration in the soil solution, (Hamdi et al., 2013; Hanes, 1999, Grattoni et al., 1993; Kanwar et al., 1980).

Agricultural activities are probably the most significant anthropogenic sources of nitrate contamination in groundwater. Nevertheless, when nitrogen-rich fertilizer application exceeds the plant demand and 
the denitrification capacity of the soil, nitrogen can leach to groundwater usually in the form of nitrate which is highly mobile with little sorption. Characterization of nitrogen sources and identification of areas with heavy nitrogen loadings from point and non-point sources is important for land use planners, environmental regulators, and is essential for developing fate and transport models. Once such high-risk areas have been identified, preventive measures can be implemented to minimize the risk of nitrate leaching to groundwater. Accurate quantification of nitrate leaching to groundwater is difficult due to the complex interaction between land use practices, on-ground nitrogen loading, groundwater recharge, soil nitrogen dynamics, and soil characteristics, (Almasri and Kaluarachchi, 2007; Lee et. al., 1991; Lee and Jose, 2005). Almasri and Kaluarachchi (2007) modeled nitrate contamination of groundwater in agricultural watersheds. They present and implements a framework for modeling the impact of land use practices and protection alternatives on nitrate pollution of groundwater in agricultural watersheds to estimate nitrate leaching to groundwater.

A theoretical analysis of the movement of nitrogen compounds in an unsaturated soil with zero-order denitrification is presented in many studies. Analytical solutions of equations describing miscible displacement for steady-flow conditions and uniform water contents are known for many boundary conditions (de Smedt and Wierenga, 1978; Kaledhonkar et al., 2001; van Genuchten and Alves, 1982; Yong et al., 1992).

The mathematical description of groundwater flow, contaminant transport and diffusion through porous media, can be found in many textbooks and monographs devoted to the development of the governing relationship and solution of the relationship subject to various initial and boundary conditions. However, that as good as the mathematical models are, and as efficient as the appropriate numerical models for solution of the complex field problems are, the quality of the inputs used, and the accuracy in representation of the physical, chemical and biological interactions with the transporting fluid and contaminants still remain as part of the essential requirements in the success of the analytical and predictive capability of the models. In the absence of proper inputs, the models will continue to render results that remain suspect.

Nitrogen $(\mathrm{N})$ is a critical nutrient needed by all plants for growth. Nitrates $\left(\mathrm{NO}_{3}{ }^{-}\right)$are the one of the principal $\mathrm{N}$ forms taken up by plants. Numerous studies have suggested that leaching of $\mathrm{NO}_{3}$-following high input rates of chemical fertilizer and due to mineralization of organic $\mathrm{N}$ already present in the soils can cause degradation of surface and groundwater quality (Almasri and Kaluarachchi, 2007; Kováčová, 2017; Siman and Velísková, 2020).

\section{Material and methods}

The movement of one or several solutes in a natural soils involves many complicated phenomena. Estimation of adsorption, transport and transformation nitrogen compounds parameters is need for modeling the movement in an unsaturated soil. The concentration vs. time curve (elution curve) contains most of the information on the interaction between the solute and the soil.

A theoretical analysis of the movement of nitrogen compounds in unsaturated soil with zero-order denitrification is presented in many studies. Analytical solutions of equations describing miscible displacement for steady-flow conditions and uniform water contents are known for many boundary conditions.

The differential equation in the one-dimensional form used for consideration of advective-dispersive transport assume isothermal conditions, difference, no-volume change conditions is written (van Genuchten and Alves, 1982; Yong et al., 1992).

For one-dimensional flow the hydrodynamic dispersion equation for a noninteracting solute were described (van Genuchten and Wierenga, 1986):

$$
\frac{\partial(\theta c)}{\partial t}=\frac{\partial}{\partial x}\left[D \frac{\partial(\theta c)}{\partial x}\right]-\frac{\partial(q c)}{\partial x}
$$

where:

$$
\begin{array}{ll}
c & \text { - solute mass per unit volume of solute. }\left[\mathrm{ML}^{-3}\right], \\
D & \text { - diffusion-dispersion coefficient }\left[\mathrm{L}^{2} \mathrm{~T}^{-1}\right], \\
\theta & - \text { volumetric water content }\left[\mathrm{L}^{3} \mathrm{~L}^{-3}\right], \\
q & \text { - Darcian Flux of the soil water }\left[\mathrm{LT}^{-1}\right], \\
t & - \text { time }[\mathrm{T}], \\
x & \text { - distance }[\mathrm{x}] .
\end{array}
$$

Equation (2) describing transport of water and chemicals in porous media, including sorption and microbial transformation terms is (Bolt, 1979; de Smedt and Wierenga, 1978; van Genuchten and Alves, 1982; Yong et al., 1992):

$$
\frac{\partial c}{\partial t}=D \frac{\partial^{2} c}{\partial x^{2}}-v \frac{\partial c}{\partial x}-\frac{\rho}{\theta} \frac{\partial S}{\partial t} \pm \Phi
$$

where:

$\delta S / \delta t-$ represent sorption term $\left[\mathrm{MM}^{-1} \mathrm{~T}^{-1}\right]$,

$\Phi \quad$ - represent kinetic change of chemicals $\left[\mathrm{MT}^{-1}\right]$,

$v \quad$ - average pore-water velocity $\left[\mathrm{LT}^{-1}\right]$.

The governing differential equation in the onedimensional form used for consideration of advectivedispersive transport assume isothermal conditions, absence of significant density difference, no-volume change conditions, without transformations for $i$-ion can be written:

$$
\frac{\partial c_{i}}{\partial t}=D_{i} \frac{\partial^{2} c_{i}}{\partial x^{2}}-v_{i} \frac{\partial c_{i}}{\partial x}-\frac{\rho}{\theta} \frac{\partial S_{i}}{\partial t}
$$

where:

$$
\begin{array}{ll}
D_{i} & \text { - diffusion-dispersion coefficient }\left[\mathrm{L}^{2} \mathrm{~T}^{-1}\right], \\
\rho & \text { - dry mass density }\left[\mathrm{ML}^{-3}\right], \\
v_{i} & \text { - average pore-water velocity }\left[\mathrm{LT}^{-1}\right], \\
S & \text { - adsorbed amount of ion }\left[\mathrm{MM}^{-1}\right] .
\end{array}
$$


The diffusion-dispersion coefficient accounts for the various transport-controlled processes which include dispersion (mixing) and diffusion transport of the ions in concert with the liquid movement in the pores of the soil. Parameter R (retardation factor) can be used to estimate the number of pore volumes of flow required to achieved breakthrough.

Another way of approaching the problem of modelling of contaminant transport in unsaturated soils is to conduct laboratory leaching column tests using unsaturated soil samples representative of the field situation.

If we substitute sorption item the transport equation will be in form:

$R_{i} \frac{\partial c_{i}}{\partial t}=D_{i} \frac{\partial^{2} c_{i}}{\partial x^{2}}-v_{i} \frac{\partial c_{i}}{\partial x}$

where:

$R_{i}$ - retardation factor.

Attributes of some ions (nitrate, chloride) can be used for estimation parameters $D_{i}$ and $v_{i}$ in the transport equation for non-reactive compound, when retardation factor $R \approx 1$ and for steady-state unsaturated liqiud miscible flow

$$
\frac{\partial c_{i}}{\partial t}=D_{i} \frac{\partial^{2} c_{i}}{\partial x^{2}}-v_{i} \frac{\partial c_{i}}{\partial x}
$$

For characterization of the soil solute flow with defined ion composition except the $v_{i}$ - average pore-vater velocity the values of dispersion-diffusion coefficient must be known. This parameter can be estimated by many ways. According to Gupta and Greenkorn (1974) is used for estimation $D_{i}$ equation:

$$
D_{i}=\frac{v_{i} \cdot x}{4 \pi\left(\frac{\partial c_{i}}{\partial \beta}\right)_{\beta=1}^{2}}
$$

where:

$\beta$ - pore volume,

$\beta=v_{i} . t / x$.

Lai and Jurinak (1972) used relation:

$$
D_{i}=\frac{v_{i} \cdot x}{4 \pi V_{0}^{2} S_{0}^{2}}
$$

where:

$V_{o}$ - cumulative eluate volume for concentration value $c i /(c o) i=0.5$

$S_{o}$ - direction breakthrough curve in $c_{i} /(c o)_{i}=0.5$.

\section{Description of area of interest}

The studied soil samples were taken away from the Žitný ostrov area (Slovakia). The Žitný ostrov is one of the most productive agricultural areas of Slovakia, situated on the Danube Lowland. Under its surface is the richest water reservoir of Slovakia. For this reason, it is very important to deal with quantity and quality of water resources in this region. In terms of geomorphology, this territory can be characterised as a young riverside plain with a very low denivellisation of the surface with an overall inclination from north-west to south-east. The territory is break up in transversal as well as in longitudinal directions into different geomorphological areas. In the sense of transversal division, we recognise the upper, the middle and the lower parts of the Žitný ostrov. We distinguish the Pleistocene core, late Holocene aggradation dikes (walls) and early Holocene depressions. The early Holocene depressions are characterised by a relatively high groundwater table. In terms of climatic situations, the Žitný ostrov belongs to a very warm and very dry agroclimatic area with mild winter. In terms of hydrological conditions, the Quarternary formation of sandy gravels created conditions for accumulation of groundwaters (Čurlík and Šefčík, 1999; Koczka Bara et al., 2014).

Anthropogenic activities realized in river basins may result in a deterioration of water quality with detrimental effects on the ecosystems. Nitrate leaching from agricultural land is usually considered a non-point source pollution problem, making the specific polluter hard to identify (Čelková, 2014; Dulovičová et al., 2020; Wick et al., 2012).

Experiments studying transport of nitrate ions were conducted by soil column leaching tests in four soil columns separately. Defined geometry of the soil columns (radius $\mathrm{r}=0.03 \mathrm{~m}$, cross-section area $2.826 .10^{-3} \mathrm{~m}^{2}$, length $\mathrm{h}=0.3 \mathrm{~m}$ ) and unsaturated, steady state flow of liquid phase was used. The columns were filled up by the soil continuously. Soil samples were mechanically adapt (dried, crushed and $2 \mathrm{~mm}$ size sieved) and chemically (wash by $\mathrm{LiCl}$ ) prepare. Laboratory experiments were conducted for three pore velocity: $\mathrm{v}_{1}=3.5 .10^{-6} \mathrm{~m} \mathrm{~s}^{-1}$, $\mathrm{v}_{2}=5 \cdot 8 \cdot 10^{-7} \mathrm{~m} \cdot \mathrm{s}^{-1}, \mathrm{v}_{3}=8 \cdot 3 \cdot 10^{-8} \mathrm{~m} \cdot \mathrm{s}^{-1}$ and four initial ion concentrations: $c_{0}=100,200,300,500 \mathrm{mg} \cdot \mathrm{l}^{-1}$. Volumetric water content of the soil, determined gravimetric, take values in range $0.32-0.38 \mathrm{~cm}^{-3} \mathrm{~cm}^{-3}$. Dry mass density values were in range $1.32-1.40 \mathrm{~g} \mathrm{~cm}^{-3}$. The columns were washed by defined volume $\mathrm{V}=500 \mathrm{~cm}^{3}$. The time changes of nitrogen ion concentrations were observed. Nitrates were determined by spectrophotometer DR 2800 fy Hach Lange. The experiments were conducted in $\mathrm{pH} 6.5$ and $\mathrm{t}=25^{\circ} \mathrm{C}$ conditions.

\section{Results and discussion}

Measured values were graphically plotted as function $c_{i} /\left(c_{i}\right)_{o}=f(t)$. The dispersion-diffusion coefficients $D_{i}$ were estimated from the equation suggested by Lai and Jurinak (1972). For laboratory experiments were used soil samples from locality Okoličná na Ostrove (Calcarohaplic Phaeozem), characterful for Žitný ostrov. The soil texture, physical and chemical properties were determined and are presented in Table 1-3. 
This locality was irrigated from Komárňanský channel water with high nitrate concentration level. In study Kováčová, (2020) surface water quality data collected from monitoring sites of Žitný ostrov channel network during the years from 1987 to 2019 were analyzed. The analysis allowed to identify long-term trends of the water quality.

The channel network at the Žitný Ostrov area was built up for drainage and also to provide irrigation water. Komárňanský channel is one of three main channels of this network: Komárňanský channel - is the P1M water body type (partial river-basin Váh, code SKV0226). For the evaluation the water quality we went out from the data obtained on Institute of Hydrology SAS during the 1987-2019.

The quantity of nitrates was evaluated according to Direction of SR government no.269/2010 for establishing requirements for obtaining the good water conditions, resp. previously valid norm STN 757221. Measurements for the Komárňanský channel show that the permitted values were exceeded sporadically in some months in the years 1987-2019.

The dependences $c / c o=f(t)$ (breakthrough curves) were plotted and the values of $(c / c o)_{\max }, t(c / c o)_{\max }$ were obtain (Fig. 1).

The diffusion-dispersion coefficients for nitrate were estimated (Table 4). The concentration profiles were estimated and was investigated the influence of the flow electrolyte velocity on the change of nitrates ions concentration in the soil columns at defined conditions. From measuring values it follows that included with decreasing the flow velocity and increasing the initial concentration, the dispersion-diffusion coefficient is decreasing. The coefficients are compareble with results of other studies of the same soil structure, (Čelková, 2014; Hanes, 1999).

Table 1. Soil texture (grain composition)

\begin{tabular}{|c|c|c|c|c|c|c|c|}
\hline \multirow[b]{2}{*}{ locality } & \multirow[b]{2}{*}{ Soil unit } & \multirow[b]{2}{*}{$\begin{array}{l}\text { Sample depth } \\
{[\mathrm{m}]}\end{array}$} & \multicolumn{2}{|c|}{ Sand [\%] } & \multicolumn{2}{|c|}{ Silt [\%] } & \multirow{2}{*}{$\begin{array}{c}\text { Clay [\%] } \\
<0.001 \\
{[\mathrm{~mm}]}\end{array}$} \\
\hline & & & $\begin{array}{r}>0.25 \\
{[\mathrm{n}}\end{array}$ & -0.05 & 0.05-0 & 0.001 & \\
\hline \multirow{3}{*}{$\begin{array}{l}\text { Okoličná } \\
\text { na Ostrove }\end{array}$} & \multirow{3}{*}{$\begin{array}{l}\text { Calcaro- } \\
\text { haplic } \\
\text { Phaeozem }\end{array}$} & $0.1-0.3$ & 7 & 18 & 38 & 37 & 15.6 \\
\hline & & $0.4-0.7$ & 7 & 16 & 42 & 35 & 16.1 \\
\hline & & $0.7-1.0$ & 11 & 19 & 41 & 29 & 14.3 \\
\hline
\end{tabular}

Table 2. Physical properties

\begin{tabular}{|c|c|c|c|c|c|c|c|c|}
\hline locality & $\begin{array}{l}\text { Sample } \\
\text { depth }\end{array}$ & $\rho_{s}$ & $\rho d$ & $P$ & $\theta_{F C}$ & $\theta_{P D A}$ & $\theta_{W P}$ & $\mathrm{AC}$ \\
\hline & {$[\mathbf{m}]$} & {$\left[\mathrm{g} \mathrm{cm}^{-3}\right]$} & {$\left[\mathrm{g} \mathrm{cm}^{-3}\right]$} & {$[\%]$} & pF 2.3 & pF 3.4 & pF 4.2 & [\%] \\
\hline \multirow{3}{*}{$\begin{array}{l}\text { Okoličná } \\
\text { na Ostrove }\end{array}$} & $0.1-0.3$ & 2.70 & 1.62 & 40 & 34.1 & 21.5 & 15.4 & 10.8 \\
\hline & $0.4-0.7$ & 2.72 & 1.47 & 45.9 & 33.8 & 19.8 & 16.6 & 7.9 \\
\hline & $0.7-1.0$ & 2.73 & 1.54 & 43.5 & 29.6 & 17.3 & 15.3 & 5.6 \\
\hline
\end{tabular}

$\rho_{s /} \rho_{d}-$ particle/bulk density, $P$ - tot. porosity, $\theta_{F C}-$ field cap., $\theta_{P D A}-$ point of dec. avail., $\theta_{W P}-$ wilting point, $\mathrm{AC}-\min$. air capacity

Table 3. Chemical attributes

\begin{tabular}{|c|c|c|c|c|c|c|c|c|}
\hline \multirow[t]{2}{*}{ locality } & \multirow{2}{*}{$\frac{\text { Depth }}{[\mathrm{m}]}$} & \multicolumn{2}{|c|}{ pH } & \multirow{2}{*}{$\frac{\mathrm{CaCO}_{3}}{[\%]}$} & \multirow{2}{*}{$\frac{\operatorname{Cox}}{[\%]}$} & \multirow{2}{*}{$\frac{\text { Humus }}{[\%]}$} & \multirow{2}{*}{$\frac{\mathrm{EC}}{\left[\mathrm{mS} \mathrm{m}^{-1}\right]}$} & \multirow{2}{*}{$\frac{\text { ESP }}{[\%]}$} \\
\hline & & $\mathbf{H}_{2} \mathbf{O}$ & $\mathrm{KCl}$ & & & & & \\
\hline \multirow{3}{*}{$\begin{array}{l}\text { Okoličná } \\
\text { na Ostrove }\end{array}$} & $0.1-0.3$ & 7.9 & 7.6 & 29 & 1.8 & 3.5 & 95 & 3.15 \\
\hline & $0.4-0.7$ & 8.2 & 7.8 & 32 & 1.9 & 3.7 & 82 & 2.75 \\
\hline & $0.7-1.0$ & 8.4 & 7.9 & 30 & 1.2 & 2.8 & 113 & 2.51 \\
\hline
\end{tabular}

$\mathrm{CaCO}_{3}$ - cont. of carbonates, Cox - organic carbon, EC - electrical conductivity, ESP - exchangeable sodium percentage 


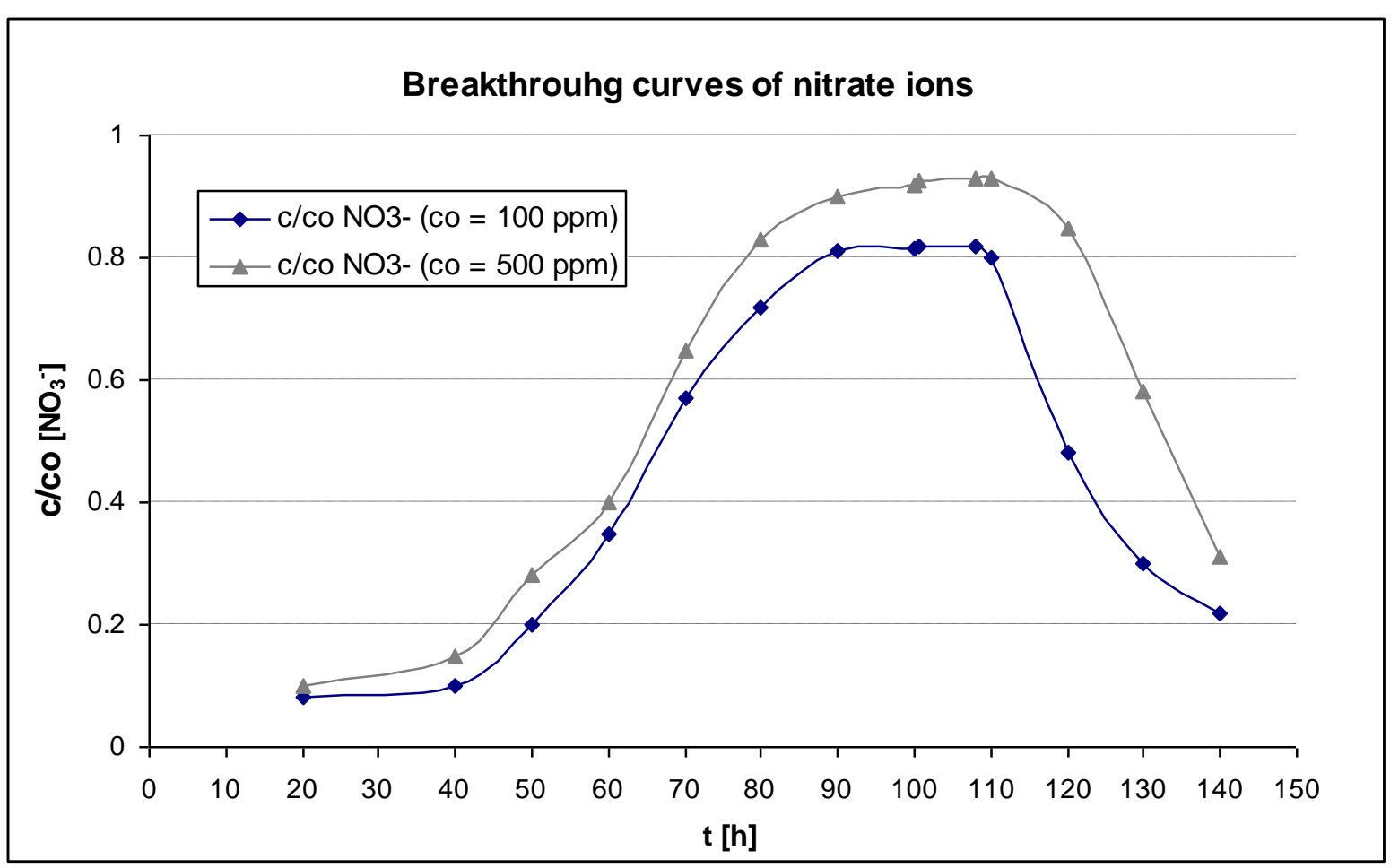

Fig. 1. Measured breakthrough curves for $\mathrm{NO}_{3}^{-}$ions stemming from a pulse of $\mathrm{NO}_{3}{ }^{-}$ (100 and $500 \mathrm{mg} \mathrm{l}^{-1}$ ) leached through the short soil column at $25^{\circ} \mathrm{C}$ ( pore velocity $\left.v_{1}=3.5 .10^{-6} \mathrm{~m} \mathrm{~s}^{-1}\right)$.

Table 4. Dynamic parameters of the columns

\begin{tabular}{|c|c|c|c|c|}
\hline$c_{o} \mathrm{mg} \mathrm{l}^{-1} \mathrm{NO}_{3}^{-}$ & 100 & 200 & 300 & 500 \\
\hline$\theta\left[\mathrm{cm}^{3} \mathrm{~cm}^{-3}\right]$ & 0.32 & 0.35 & 0.33 & 0.35 \\
\hline \multirow[t]{2}{*}{$\rho\left[\mathrm{g} \mathrm{cm}^{-3}\right]$} & 1.32 & 1.38 & 1.40 & 1.35 \\
\hline & \multicolumn{4}{|c|}{$\mathrm{v}_{1}=3.5 \times 10^{-6} \mathrm{~m} \mathrm{~s}^{-1}$} \\
\hline$(c / c o)_{\max }$ & 0.82 & 0.85 & 0.88 & 0.93 \\
\hline$t_{(c / c o) \max }[\mathbf{h}]$ & 100.5 & 102.3 & 105.0 & 108.3 \\
\hline \multirow[t]{2}{*}{$D\left[\mathrm{~m}^{2} \mathrm{~s}^{-1}\right]$} & $2.1 \times 10^{-9}$ & $2.3 \times 10^{-9}$ & $1.2 \times 10^{-9}$ & $9.9 \times 10^{-9}$ \\
\hline & \multicolumn{4}{|c|}{$\mathrm{v}_{2}=5.8 \times 10^{-7} \mathrm{~m} \mathrm{~s}^{-1}$} \\
\hline$(c / c o)_{\max }$ & 0.85 & 0.87 & 0.92 & 0.95 \\
\hline$t_{(c / c o) \max }[\mathbf{h}]$ & 140.3 & 143.2 & 145.2 & 148.4 \\
\hline \multirow[t]{2}{*}{$D\left[\mathrm{~m}^{2} \mathrm{~s}^{-1}\right]$} & $3.7 \times 10^{-10}$ & $4.6 \times 10^{-10}$ & $3.2 \times 10^{-10}$ & $2.5 \times 10^{-10}$ \\
\hline & \multicolumn{4}{|c|}{$\mathrm{v}_{3}=8.3 \times 10^{-8} \mathrm{~m} \mathrm{~s}^{-1}$} \\
\hline$(c / c o)_{\max }$ & 0.85 & 0.90 & 0.94 & 0.95 \\
\hline$t_{(c / c o) \max }[\mathbf{h}]$ & 210.0 & 218.5 & 225.0 & 230.5 \\
\hline$D\left[\mathrm{~m}^{2} \mathrm{~s}^{-1}\right]$ & $5.2 \times 10^{-11}$ & $7.2 \times 10^{-11}$ & $9.1 \times 10^{-11}$ & $1.1 \times 10^{-12}$ \\
\hline
\end{tabular}




\section{Conclusion}

Many practices result in non-point source pollution of groundwater and the effects of these practices accumulate over time. These sources include fertilizer and manure applications, dissolved nitrogen in precipitation, irrigation flows, and dry atmospheric deposition.

The resulting process of the nitrates migration may be characterized with the solution of partial processes of the dispersion type, adsorption type, transformations type etc. Estimation of transport, adsorption and transformation nitrogen compounds parameters is need for modelling the movement in an unsaturated soil.

In this paper the main role was directed on the behaviour out the nitrate ions in dynamical conditions of the electrolyte flow. The concentration profiles were estimated and was investigated the influence of the flow electrolyte velocity on the change of nitrates ions concentration in the soil columns at defined conditions. The quantitative parameters of the transport equation were investigated.

The experiments studying transport of nitrogen ions were conducted by soil column leaching tests for unsaturated steady-state flow, defined geometry of the soil columns, defined volumetric water content, dry mass density. Measured values were depicted as a function $c /(c) o=f(t)$. The experiments were conducted for various average pore velocities $\quad \mathrm{v}_{1}=3.5 \times 10^{-6} \mathrm{~m} \mathrm{~s}^{-1}, \quad \mathrm{v}_{2}=8 \times 10^{-7} \mathrm{~m} \mathrm{~s}^{-1}$, $\mathrm{v}^{3}=8.3 \times 10^{-8} \mathrm{~m} \mathrm{~s}^{-1}$ and four initial ion concentrations: $\mathrm{c}_{\mathrm{o}}=100,200,300,500 \mathrm{mg} \mathrm{l}^{-1}$. By interpreting of $c / c o=f(t)$ dependences (breakthrough curves) the significant values of $(c / c o)_{\max }$ and $t(c / c o)_{\text {max }}$ for nitrogen ions were obtained and the dispersion-diffusion coefficients $D_{i}$ were estimated. The transport parameters were obtained for soil, representative for Žitný ostrov as the input values for mathematical modelling of the movement of nitrogen compounds in this region.

From measuring values it follows that included with decreasing the flow velocity the dispersion-diffusion coefficient is decreasing.

\section{Acknowledgement}

This contribution was supported by project VEGA 2/0025/19 and project VEGA 1/0085/20.

\section{References}

Almasri, M. N., Kaluarachchi, J. J. (2007): Modeling nitrate contamination of groundwater in agricultural watersheds. J. of Hydrology, 343, 215-229. DOI: http://dx.doi.org/ 10.1016/j.jhydrol.2007.06.016

Bolt, G. H., (1979): Soil chemistry. B. Physico-chemical models. Amsterdam, Elsevier.

Curtin, D., Steppuhn, H., Selles, F. (1994): Structural stability of Chernozemic soils as affected by exchangeable sodium and electrolyte concentration. Can. J. Soil Sci., 74, 157-164.

Čelková, A. (2014): Analysis of reactive solute transport experiments in soil profile. In Növénytermelés, 2014, vol.63, supplement, 169-172.
DOI:http://dx.doi.org/10.1007/3-540-26746-8_13

Čurlík, J., Šefč́k, P. (1999): Geochemical atlas of the Slovak republic : Part V - Soils, Soil Sci. and Conservation Research Institute, Bratislava.

de Smedt, F., Wierenga, P. J. (1978): Solute Transport Through Soil With Nonuniform Water Content. Soil Sci. Soc. Am. J., vol.42, 873-879. DOI: http://dx.doi.org/ 10.2136/sssaj1978.03615995004200010002x

Dulovičová, R., Schügerl, R., Velísková, Y. (2020): Actual values of saturated hydraulic conductivity of channel bed silt and its distribution along Komárňanský channel. Acta Hydrologica Slovaca, Vol. 21, No. 1, 2020, 98-105, doi: $10.31577 / \mathrm{a}$ (hs-2020-0021.01.0012

Džatko, M. (2004): Land use and soil anthropization. Soil Anthropization VIII - Proceedings of International Conference, Soil Science and Conservation Research Institute, Bratislava, 132.

Grattoni, C. A., Dawe, R. A., Bidner, M. S. (1993): On the simultaneous determination of dispersion and nonlinear adsorption parameters from displacement tests by using numerical models and optimalisation techniques. Advances ins Water Resour., 16, 127-135. DOI: http://dx.doi.org/10.1016/0309-1708(93)90003-x

Gupta, S. P., Greenkorn, R. A. (1974): Determination of dispersion and non-linear adsorption parameters for flow in porous media. Water Resour. Res., 10, 839-846. DOI: http://dx.doi.org/10.1029/wr010i004p00839

Hamdi, W., Gamaoun, F., Pelster, D.E., Seffen, M. (2013): Nitrate Sorption in an Agricultural Soil Profile. Applied and Environmental Soil Science, Vol. 2013, http:// dx.doi.org/10.1155/2013/597824.

Hanes, J. (1999): Analysis of sorption attributes of soils. Soil Sci. and Conservation Research Institute, Bratislava, 138.

Kaledhonkar, M. J., Tyagi, N. K., van der Zee (2001): Solute transport modelling in soil for irrigation field experiments with alkali water. Agricultural Water Management, 51, 2, 153-171. DOI: http://dx.doi.org/10.1016/s0378-3774(01) 00100-7

Kanwar, R. S., Baker, J. L., Johnson, H. P., Kirkham, D. (1980): Nitrate Movement with Zero-order Denitrifiction in a Soil Profile. Soil Sci. Soc. Am. J., vol.44, 898-902. DOI: http://dx.doi.org/10.2136/sssaj1980.036159950044 $00050003 \mathrm{x}$

Koczka Bara, M., Velísková, Y., Dulovičová, R., Schügerl, R. (2014): Influence of surface water level fluctuation and riverbed sediment deposits on groundwater regime. Journal of Hydrology and Hydromechanics, vol. 62, no. 3, 177-185. DOI: http://dx.doi.org/10.2478/johh-2014-0030

Kováčová, V., Velísková, Y., (2013): Evaluation of surface water qualitative parameters in Žitný ostrov area from the nitrogen compounds position. Acta Hydrologica Slovaca, 14, 1, 133-142.

Kováčová, V. (2017): Trendy vývoja obsahu dusičnanov v kanálovej sieti Žitného ostrova [Trends of nitrate ions content in Žitný ostrov channel network]. In Acta Hydrologica Slovaca, 2017, roč. 18, č. 1, p. 57-67. ISSN 1335-6291.

Kováčová, V. (2020): Assessment of surface water eutrophication at Žitný ostrov region. Acta Hydrologica Slovaca, Vol. 21, No. 1, 2020, 65-73, doi: 10.31577/ahs2020-0021.01.0008

Lai, S. H., Jurinak, J. J. (1972): Cation adsorption in one dimensioanl flow through soils, WRK, 8, 99-102.

Lee, K. H., Jose, S. (2005): Nitrate leaching in cottonwood and loblolly pine biomass plantations along a nitrogen fertilization gradient. Agriculture, Ecosystems and Environment, 105, 615-623. 
Lee, Y. W., Dahab, M. F., Bogardi, I. (1991): Nitrate risk management under uncertainty. Journal of Water Resources Planning and Management, 118, 2, 151- 65.

Siman, C., Velísková, Y. (2020): Impact of different proportion of agricultural land in river catchments on nitrogen surface streams pollution. Acta Hydrologica Slovaca, Vol. 21, No. 1, 2020, 56-64, doi: 10.31577/ahs2020-0021.01.0007

van Genuchten, M. Th., Alves, W. J. (1982): Analytical solutions of the one-dimensional convestive-dispersive solute transport equation. U.S. Department of Agriculture, Technical Bull. 1661, 151.

DOI: http://dx.doi.org/10.1016/0012-8252(83)90054-5 van Genuchten, M. Th., Wierenga, P. J. (1986): Solute Dispersion Coefficients and Retardation Factors. Am. Soc. of Agronomy - Soil Sc. Soc. of America, Methods of soil Analysis. Part I. Physical and Mineralogical Methods, Madison, USA, 1025-1054. DOI: http://dx.doi.org/ 10.2136/sssabookser5.1.2ed.c44

Wick K., Heumesser Ch., Schmid E. (2012): Groundwater nitrate contamination: Factors and indicators. Journal of Enviromental Management (111), 178-186. DOI:

Yong, R. N., Mohamed, A. M. O., Warkentin, B. P. (1992): Principles of Contaminant Transport in Soils, Elsevier Science Publishers B.V, 327.

DOI: http://dx.doi.org/ 10.1201/b17405-11

Ing. Viera Kováčová ("corresponding author, e-mail: kovacova@uh.savba.sk)

Institute of Hydrology SAS

Dúbravská cesta 9

84104 Bratislava

Slovak Republic 